Article

\title{
Construction Project Change Management in the Democratic Republic of the Congo: Status, Causes, and Impacts
}

\author{
Bauma Frigeant Bitamba (D) and Sung-Hoon An * \\ Department of Architecture Engineering, Daegu University, Gyeongsan 38453, Korea; bauma@daegu.ac.kr \\ * Correspondence: shan@daegu.ac.kr; Tel.: +82-53-850-6518
}

Received: 29 October 2020; Accepted: 20 November 2020; Published: 23 November 2020

\begin{abstract}
Changes in construction projects are very frequent and are expected to occur at any stage of the project. These changes modify the original scope of work and affect the project in various aspects. To minimize these effects, there is a need to implement a systematic change management system during the construction process. This study aimed to investigate the current situation of change management implementation, identify the main causes of change management, and assess their impacts in the Congolese construction industry. A comprehensive literature review was conducted for a thorough understanding of change management, and a structured survey was conducted. The collected survey data were analyzed using the relative importance index (RII), and Statistical Package for the Social Sciences (SPSS) methods. The results conclude that the change management implementation situation in the Congolese construction industry is significantly high, and the project cost and the project type play a major role in the implementation of change management in the construction projects. The study further revealed that the main causes of changes were the project, contractor, materials, equipment, and other causes. These changes impact the project significantly in terms of organization, owner and contractor, project, materials, and equipment.
\end{abstract}

Keywords: Congolese construction industry; construction change management; implementation of change; causes of change; impacts of change

\section{Introduction}

The construction industry is one of the key sectors that significantly contribute to the development and economic growth of developing countries [1]. As in most developing countries, the construction industry in D.R. Congo occupies an important position in its economic progress. Therefore, it is very important to sustain the successful output with improved efficiency such as cost-effectiveness and timeliness of construction projects. A construction project is a collection of multi-organizations that differ in nature, size, duration, and complexity. Along with this, it is known that the construction industry is a very complex and fragmented sector. Many construction projects suffer from progress-related issues due to several parameters. One of the most common issues that occur in construction projects is project change, which can occur at any stage from project conception to construction [2]. Project changes are unavoidable during the construction phases from small to major modifications due to different causes from different sources. The changes occur due to the modifications in the planned work sequence, changes in construction materials and methods, and corrections due to errors or omissions which are different from the original plan. These result in a diversity of work quality, scope variations, and confusion which make the construction project uncertain [3]. These uncertainties are the major risk factors in the progress of construction. Moreover, these changes also result in consecutive delays in the schedule, project interruptions, extra demands of work, increased construction costs, labor, 
overtime, and other significant impacts [4-9]. According to Lavikka et al. [10], the different additions, modifications, and deletions of project objectives or scope adopted during the construction project progress are considered to be a change that may have both positive and negative impacts on the project output. Based on the positive and negative effects of changes in the construction projects, two principal types of changes are defined as beneficial and detrimental changes [11]. The beneficial changes can be implemented by the practice of value management. These changes further contribute to the analysis of reactive and proactive changes. Reactive changes place construction projects at an initially expected level of performance, while proactive changes seek to improve the project performance and attain the targets initially [11]. On the other hand, detrimental changes have a negative impact on project performance and have been adopted to compromise the financial value of the client [12,13]. These changes are generally determined to replace high-quality, standard, and expensive materials with sub-standard and cheap materials when the client faces financial difficulties. The detrimental changes lead to uncertainties and interfaces that contribute to the generation of non-viable activities such as modifications and reworks [14].

Several studies have investigated and identified different causes and sources of changes in the management of construction projects. The construction industry is a project-based sector where changes are made by three major factors: conception and planning, design, and construction. Conception and planning involve the owners/clients, design involves design/engineering consultants, and construction involves the contractors/sub-contractors. The changes related to owners/clients are the main source of changes in large-scale construction projects such as the changes to specifications, scope, and design $[2,3,5,15,16]$. Owner-related changes occur due to three reasons: lack of involvement in the design development stages, failure to understand and visualize the design, and changing opinions at the later stages of the design development steps [15]. Financial problems and request changes by the owner also contribute to the source of changes during the construction project [5]. Changes related to design are also among the most common causes due to the lack of coordination between design teams, incomplete/inconsistent drawings, errors, omissions of details, modifications, unclear initial design outlines, and incorrect description of design drawings [4,5,17]. The changes and improvements in the design, design discrepancies, and uncertainties of the design have also been found to be the change sources [17]. Other main causes occurring in a construction project are related to consultants and contractors $[18,19]$. The lack of coordination between contractor and owner, use of alternative construction methods to save money, adoption of new technologies, and additional works are also the causes of the changes related to consultants and contractors [18]. In addition, the project's external conditions such as unexpected geological, economic, and unforeseen weather conditions also considerably affect the project progress [15]. Another type of cause is the shortage of skilled manpower, equipment, resources, and materials. Changes in regulation of the government, policy changes, and economic environment also affect construction projects.

These changes lead to re-works in construction that would cause disruptions of project life cycle performance $[9,19]$. These adopted re-works cause delays in project delivery which is the origin of disputes and dissatisfactions among the parties involved in construction projects [15]. Some studies reported that changes and the lack of evaluation are the sources of delays in the progress of construction $[3,10]$. Others pointed out that the poor change management system had a serious impact on construction projects, resulting in poor project quality and increased total construction costs $[7,9,20]$. Moreover, it leads to delays in schedule, increased project costs, additional payments to contractors, cost over-runs, loss of productivity, and decreased quality standards $[3,8,15,21]$. Considering these impacts of changes in the management of construction projects, previous studies suggested that proper implementation of change management, providing regular training sessions, identifying the source, and adopting preventive measures, could be crucial to minimize the impacts of changes on a project $[2,4,22]$.

Changes are general, and it is important to confront, embrace, adapt, and use changes to have a positive impact on the situation faced by the project management team [23]. Furthermore, it is 
essential to record all the changes, and they need to be properly evaluated and managed. Change management requires a wide analysis to assess how much work is involved in implementing changes and evaluate the impact that these changes may have on the project. However, proper management of changes through a formalized change management process will have a significant impact on the project. On the other hand, changes in specifications and scope are initiated mostly by the project owners and consultants [3]. In order to eliminate these changes, the owners and consultants should allow enough time to prepare a detailed project outline [7]. Project stakeholders should consider both internal and external factors that influence construction project changes [11]. The process of identifying the areas to be changed, checking the requirements of project change, project change evaluation, and approving the project change were revealed to be the reasons for the increased effectiveness of the project cost in [24]. To reduce the increased costs, Halou et al. [23] recommended improving the administrative process of change that could encourage more reliable relationships among project participants. In addition, identifying the changes, anticipating their effects, and following standard procedures such as the change dependency framework model would help to mitigate the negative impact of changes on construction projects $[6,20,25]$. The use of building information modeling (BIM) technology in construction projects can improve project quality, shorten project duration, facilitate better cost estimation and control, and improve construction planning and monitoring [26,27].

Therefore, this study aimed to investigate the current situation of change management implementation, identify the main causes of change management, and assess their impacts in the Congolese construction industry. A quantitative study was organized, and a questionnaire was prepared with a system for collecting information from the main stakeholders related to the construction projects. The questionnaire consisted mainly of receiving perspectives from three main stakeholders working for small, medium, and large-sized construction companies in the Democratic Republic of the Congo. After that, the received data were carefully examined and analyzed using the relative importance index (RII) and Statistical Package for the Social Sciences (SPSS) methods.

\section{Methods and Analysis}

In order to accomplish the objective of this study, a structured questionnaire was conducted on a selected sample of construction professionals in Congo. A total number of seventy questionnaires was given to owners, consultants, and contractors throughout the country based on the regions to represent the nation in general. Among them, fifty-two questionnaires were received back which represents $74 \%$ of respondents. The questionnaire was largely divided into three main parts: general information about the company and respondents, implementation and extent of change management, causes of changes, and impacts of changes.

The first part of the questionnaire presented the basic profiles of companies and respondents who participated in this study. This section presents the respondent profiles from the data collected from questionnaires as shown in Table 1. From the table, the response rate of owners, consultants, and contractors was $52 \%, 25 \%$, and $23 \%$, respectively. In terms of size, $67 \%$ of respondents worked for smaller, $14 \%$ for medium, and 19\% worked for large companies, respectively. In addition, respondents with a high school diploma accounted for 35\%, 31\% with a Bachelor's degree, and $4 \%$ with a Master's degree. Moreover, $17 \%$ of the respondents had different backgrounds while $13 \%$ had been trained to work in construction projects. In the discipline-of-expertise view, site engineers, project developers, other discipline workers, and architects accounted for $56 \%, 19 \%, 13 \%$, and $12 \%$, respectively. The respondents were also evaluated and classified as persons with 5 years, 5 to 10 years, 10 to 15 years, and more than 15 years of work experience, and the rate of respondents was $61 \%, 33 \%$, $4 \%$, and $2 \%$, respectively. The second part of the questionnaire concentrated on assessing the causes that mostly affect construction projects due to change management. This consisted of a total of forty-six questions divided into eight groups of causes. From the results, the causes of change management were identified, the relative importance index (RII) was calculated, and then the average RII values for each group were calculated and categorized. The third section consisted of six groups of impacts 
of change consisting of thirty-one questions. Through this section, the significant impacts of change management on the construction projects were identified, and the RII was calculated in order to rank and categorize according to their effects on the project.

Table 1. Profile of the company and respondents.

\begin{tabular}{cccc}
\hline Characteristics & Respondents & $\mathbf{N}$ & $\%$ \\
\hline \multirow{3}{*}{ Type of organization } & Owner & 12 & $52 \%$ \\
& Consultant & 27 & $25 \%$ \\
& Contractor & 13 & $23 \%$ \\
\hline \multirow{2}{*}{ Company's size } & Small size (20 or fewer employees) & 35 & $67 \%$ \\
& Medium size (21-99 employees) & 7 & $14 \%$ \\
& Big size (100 or more employees) & 10 & $19 \%$ \\
\hline \multirow{3}{*}{ Respondent's } & Training & 7 & $13 \%$ \\
qualification & Diploma & 18 & $35 \%$ \\
& Bachelor & 16 & $31 \%$ \\
& Master & 2 & $4 \%$ \\
& Others & 9 & $17 \%$ \\
\hline \multirow{2}{*}{ Respondents job title } & Architect & 6 & $12 \%$ \\
& Developer & 10 & $19 \%$ \\
& Site Engineer & 29 & $56 \%$ \\
Respondent's working & Others & 7 & $13 \%$ \\
\hline experience & Less than 5 years & 32 & $61 \%$ \\
& $5-10$ years & 17 & $33 \%$ \\
& $10-15$ years & 2 & $4 \%$ \\
& Over 15 years & 1 & $2 \%$ \\
\hline
\end{tabular}

The above questionnaire survey aimed to define the perception of the professionals involved in construction such as owners/clients, consultants, and contractors of the causes and impacts of changes that occur in construction projects. The questionnaire was based on the 5-point Likert scale rates from very low to very high importance ( 1 to 5 scales) depending on the level of importance of both the causes and impacts of changes on the construction project. The collected data were primarily analyzed by using Microsoft Excel. The causes and their impacts were evaluated, ranked, and categorized based on the following equation:

$$
\begin{gathered}
\mathrm{RII}=\sum \frac{\mathrm{W}}{\mathrm{A} \times \mathrm{N}} \\
(0<\mathrm{RII} \leq 1)
\end{gathered}
$$

where RII = relative importance index, $\mathrm{W}=$ weight given to each factor by respondents (ranging from 1 to 5$), A=$ highest weight ( 5 in this case), and $\mathrm{N}=$ total number of respondents. The RII values should be obtained in the range from 0 to $1(0<$ RII $\leq 1)$. The higher the RII values (RII $\leq 1)$, the greater the causes and impacts, and the lower values $(0>$ RII $)$ indicate the lesser. Finally, the Spearman ( $\rho$ ) [28] rank correlation coefficient was used to measure the difference in ranking between two groups of respondents (e.g., owners/clients vs. consultants, owners/clients vs. contractors, and consultants vs. contractors) who scored on various factors. The Spearman $(\rho)$ rank correlation coefficient was calculated using the following equation:

$$
\operatorname{Rho}(\rho)=1-\frac{6 \times\left(\sum \mathrm{di}^{2}\right)}{\mathrm{n} \times\left(\mathrm{n}^{2}-1\right)}
$$

where Rho $(\rho)$ is Spearman's rank correlation coefficient, di is the difference in ranking between each pair of factors, and $\mathrm{n}$ is the number of factors. The value of the Spearman (Rho) rank correlation coefficient lies in the range between -1 and +1 . The obtained coefficients indicate perfect positive correlation (+1), no correlation (0), and perfect negative correlation $(-1)$. 


\section{Results and Discussion}

\subsection{Decision Factors that Determine the Implementation of Change Management}

Figure 1a shows the extent of change management implementation in the Congolese construction industry. The $X$ and $Y$ axes represent the extent of change management implementation and the number of respondents. From the figure, a total of seven respondents said that they did not implement changes at all, while ten respondents said the implementation was less than $50 \%$. Furthermore, fifteen, three, and seventeen respondents said the change management was implemented at $50 \%,>50 \%$, and in all the projects $(100 \%)$, respectively. This analysis showed that the extent of change management implementation in the Congolese construction industry was significantly higher (from 50\% to $100 \%$ ). Therefore, it is very important to identify the decision factors in implementing change management. To identify these factors, the survey questionnaire included five key factors: project type, project size, project nature, owner's request, and project cost were listed, and the respondents were required to list the factors that encouraged the most to implement the change management. The decision factors for the implementation of change management in the Congolese construction industry were analyzed and are presented in Figure 1b. From the figure, nineteen and thirteen respondents indicated that the decision factors for the implantation of changes were project cost and type. Seven respondents pointed out owner's request and another seven respondents indicated project nature for implementing change management. Finally, according to the six respondents, project size was found to be the factor least encouraging the implementation of change management. Based on the above results, the factors most encouraging construction companies to implement change management in their projects were project cost and project type. According to Zou et al. [29], project cost is the most sensitive and influential part of construction projects.

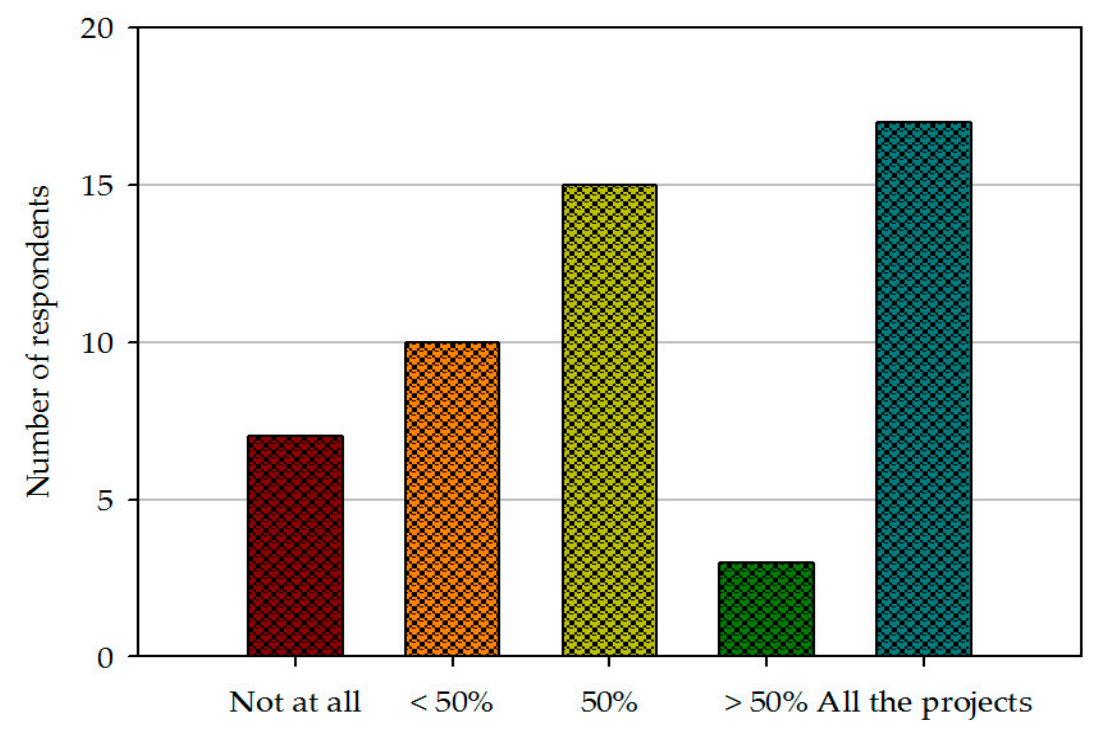

Extent of change management implementation

(a)

Figure 1. Cont. 


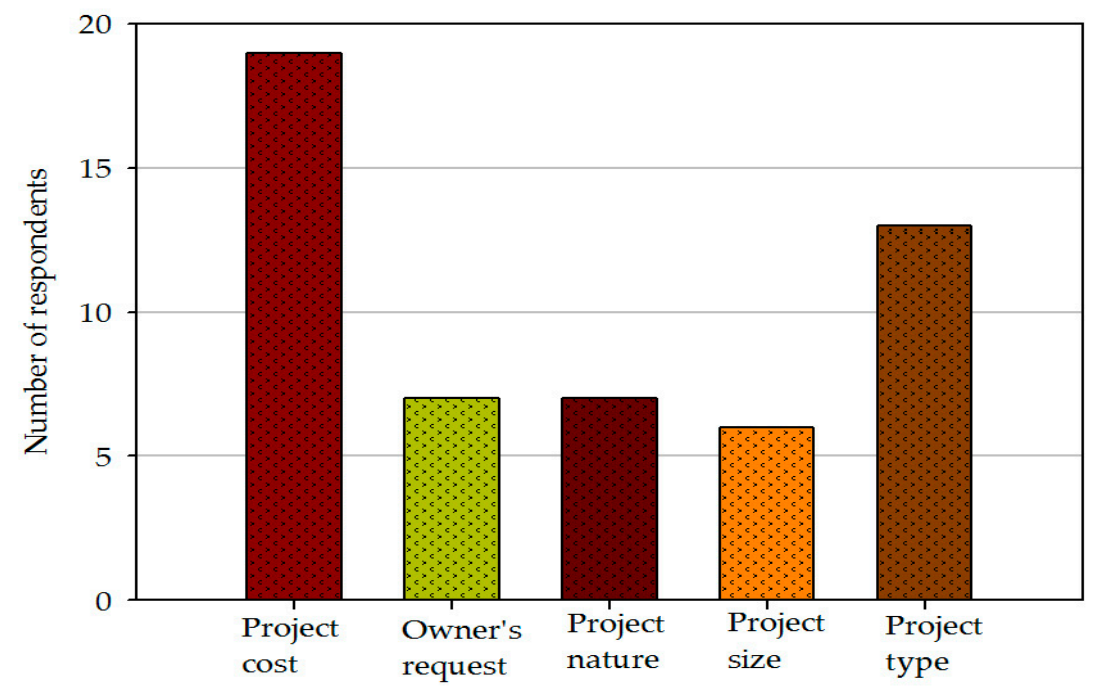

Decision factors for implementation of change management

(b)

Figure 1. (a) Extent of change management implementation; (b) Decision factors for the implementation of change management.

\subsection{Causes of Changes}

Table 2 shows the results of the RII analysis of the causes of change management opinions of the main stakeholders: owners, consultants, and contractors involved in the construction projects of Congo. The overall RII average analysis results show that the project-related changes had a higher RII value of 0.69 , while changes related to the contractor, materials and equipment, and economy and government regulations had an RII average value of 0.68 , respectively. Changes related to the design, organizational and management, environmental conditions, and the owner showed the average RII values of 0.67 , $0.65,0.65$, and 0.64 , respectively. These overall RII average values of causes of change management are shown in Figure 2. The above results indicate that the four main causes for change management in the construction projects of Congo were changes related to the project, contractor, materials and equipment, and economy and government regulations. These four main causes were mainly considered in this study and explained more in detail. In the project-related causes, the findings reveal the inaccurate cost estimating and shortage of financial status of any party involved in the project to be the highly influencing factors with the RII values of 0.72 and 0.69 , respectively. Project complexity and change of the financial status of any party involved in the project were also found to be less influential to project-related changes with the common RII values of 0.68 . To improve project-related changes, the involved parties should provide proper cost estimating without any mistakes. Along with this, project stakeholders should ensure enough financial, material, and skilled human resources available throughout the project to avoid shortage. In the contractor-related changes, the contractor's desire to improve the quality of work at the site was found to be the most influential factor with the RII value of 0.74. In addition, the rectification of construction mistakes, contractor's desire to improve the financial conditions, and contractor's financial difficulties were found to influence the contractor-related causes with RII values 0.70 for each, respectively. The contractors should not apply any decisions for the improvement of work, and any decisions to improve can be made before implementing at the site. In addition, the unavailability of equipment and specification in materials influence the most in the changes related to materials and equipment with 0.71 and 0.70 RII values. The equipment and materials need to be available throughout the progress of construction. The changes related to the economy and government were influenced by the new government regulations and change in the economic 
conditions of the country with the RII values of 0.73 and 0.67 , respectively. These external factors that are not associated with the stakeholders can also be considered in advance while the project planning is elaborated. In design-related changes, design improvements and errors and omissions of details in design were discovered to influence the change management the most with an RII average of 0.78 and 0.75 , respectively. The employment of a skilled and experienced design team can reduce these errors and mistakes in the designs.

From the overall RII results, the peak five individual factors that cause the implementation of change management were identified and are presented in Figure 3. The design improvements with the 0.78 RII value was found to be ranked as first and followed by the contractor's willingness to improve the quality of work as second with the RII value of 0.76 . The errors and omissions of details in design, the owner's financial difficulties, and changes in new government regulations were further ranked as third, fourth, and fifth with the RII values of $0.75,0.74$, and 0.73 , respectively.

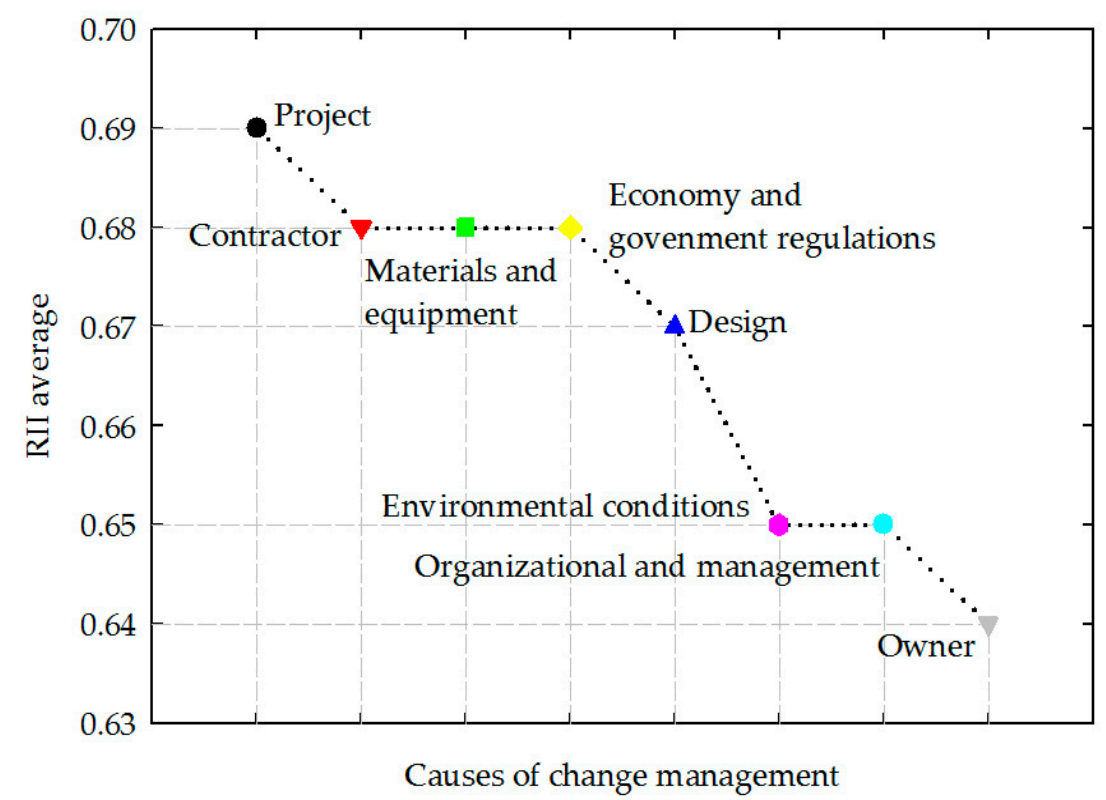

Figure 2. Average for the causes of changes.

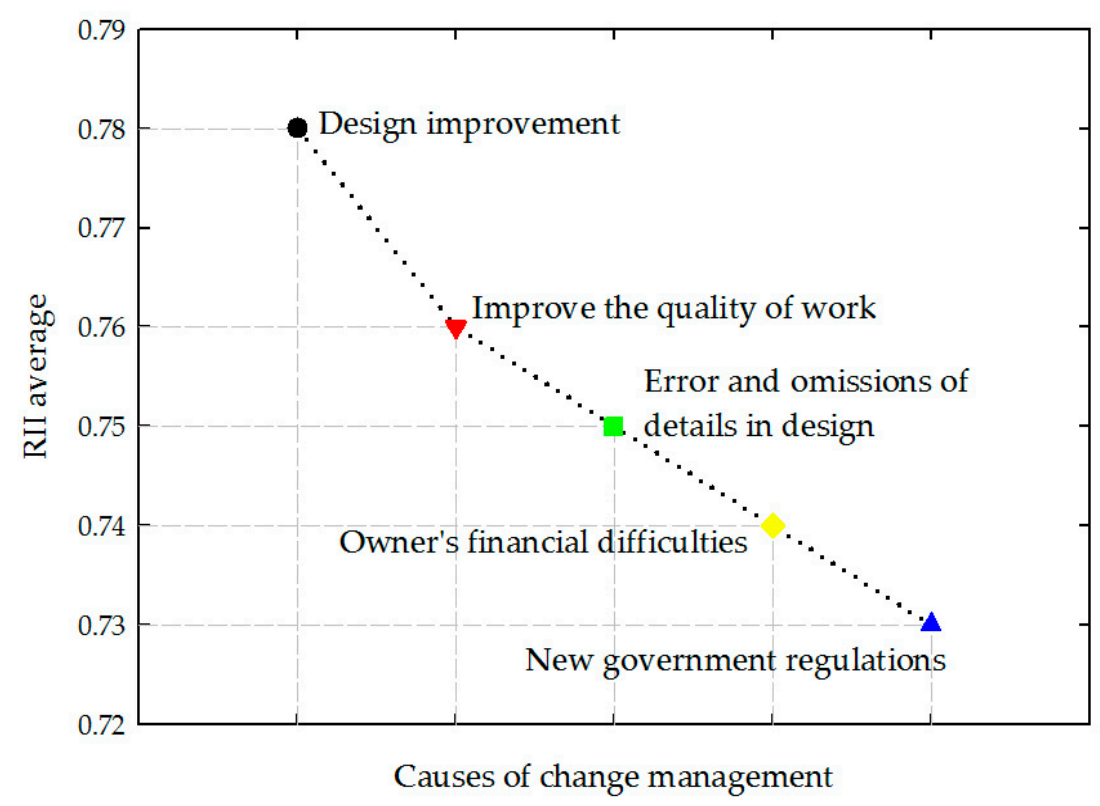

Figure 3. Peak causes of change management. 
Table 2. Field survey showing the results of causes of change management from the relative importance index (RII) analysis.

\begin{tabular}{|c|c|c|c|c|c|c|c|c|}
\hline \multirow{3}{*}{ Causes of Changes } & \multicolumn{8}{|c|}{ Organization } \\
\hline & \multicolumn{2}{|c|}{ Owner } & \multicolumn{2}{|c|}{ Consultant } & \multicolumn{2}{|c|}{ Contractor } & \multicolumn{2}{|c|}{ Overall Average } \\
\hline & RII & Rank & RII & Rank & RII & Rank & RII & Rank \\
\hline \multicolumn{3}{|l|}{ Design-related changes } & \multicolumn{6}{|c|}{ RII Average $=0.67$} \\
\hline Error and omissions of details in design & 0.82 & 1 & 0.76 & 3 & 0.66 & 3 & 0.75 & 2 \\
\hline Uncertainty and complexity of design & 0.73 & 3 & 0.73 & 4 & 0.55 & 5 & 0.67 & 5 \\
\hline Balancing feedback in design & 0.67 & 5 & 0.71 & 5 & 0.69 & 2 & 0.69 & 4 \\
\hline Lack of coordination during the design & 0.65 & 6 & 0.61 & 7 & 0.48 & 7 & 0.58 & 7 \\
\hline Modification of the original design & 0.60 & 8 & 0.63 & 6 & 0.69 & 2 & 0.64 & 6 \\
\hline Dimensional error in architectural drawings & 0.72 & 4 & 0.82 & 1 & 0.60 & 4 & 0.71 & 3 \\
\hline Design improvements & 0.75 & 2 & 0.78 & 2 & 0.82 & 1 & 0.78 & 1 \\
\hline Design change of mind & 0.63 & 7 & 0.52 & 8 & 0.52 & 6 & 0.56 & 8 \\
\hline \multicolumn{3}{|l|}{ Contractor-related changes } & \multicolumn{6}{|c|}{ RII Average $=0.68$} \\
\hline Lack of coordination between contractor and owner & 0.73 & 2 & 0.62 & 6 & 0.66 & 2 & 0.67 & 4 \\
\hline Additional work & 0.68 & 5 & 0.75 & 4 & 0.60 & 5 & 0.68 & 3 \\
\hline Construction method change (adopt new technology) & 0.58 & 6 & 0.69 & 5 & 0.62 & 4 & 0.63 & 6 \\
\hline Rectification of construction mistakes & 0.70 & 4 & 0.76 & 3 & 0.65 & 3 & 0.70 & 2 \\
\hline Improving the quality of work at site & 070 & 4 & 0.77 & 2 & 0.82 & 1 & 0.76 & 1 \\
\hline Use of alternative construction method to save money & 0.72 & 3 & 0.69 & 5 & 0.54 & 6 & 0.65 & 5 \\
\hline Contractor's desire to improve the financial conditions & 0.68 & 5 & 0.78 & 1 & 0.65 & 3 & 0.70 & 2 \\
\hline Contractor financial difficulties & 0.75 & 1 & 0.75 & 4 & 0.60 & 5 & 0.70 & 2 \\
\hline \multicolumn{3}{|l|}{ Owner-related changes } & \multicolumn{6}{|c|}{ RII Average $=0.64$} \\
\hline Change of plans (design) by the owner & 0.63 & 3 & 0.67 & 4 & 0.57 & 2 & 0.62 & 3 \\
\hline Schedule change by the owner & 0.67 & 2 & 0.62 & 5 & 0.57 & 2 & 0.62 & 3 \\
\hline Change in specification and scope of work by the owner & 0.62 & 4 & 0.70 & 3 & 0.49 & 3 & 0.60 & 4 \\
\hline Owner's financial difficulties & 0.82 & 1 & 0.80 & 1 & 0.60 & 1 & 0.74 & 1 \\
\hline Additional or reduction of works/scope (not part of the original litter) by the owner & 0.60 & 5 & 0.72 & 2 & 0.57 & 2 & 0.63 & 2 \\
\hline \multicolumn{3}{|l|}{ Organizational and management-related changes } & \multicolumn{6}{|c|}{ RII Average $=0.65$} \\
\hline Change in management & 0.73 & 2 & 0.72 & 2 & 0.59 & 3 & 0.68 & 2 \\
\hline Lack of timely and effective communication & 0.60 & 7 & 0.73 & 1 & 0.66 & 1 & 0.66 & 4 \\
\hline Lack of integration between departments & 0.62 & 6 & 0.61 & 6 & 0.57 & 4 & 0.60 & 6 \\
\hline Poor project management & 0.68 & 4 & 0.71 & 3 & 0.57 & 4 & 0.65 & 5 \\
\hline Inadequate working drawing details & 0.62 & 6 & 0.73 & 1 & 0.62 & 2 & 0.66 & 4 \\
\hline Ambiguity in project goal or scope & 0.72 & 3 & 0.70 & 4 & 0.59 & 3 & 0.67 & 3 \\
\hline Shortage of skilled manpower & 0.75 & 1 & 0.73 & 1 & 0.57 & 4 & 0.68 & 2 \\
\hline Poor procurement process & 0.73 & 2 & 0.73 & 1 & 0.62 & 2 & 0.69 & 1 \\
\hline Changes to organizational processes & 0.63 & 5 & 0.70 & 4 & 0.52 & 5 & 0.62 & 7 \\
\hline Co-ordination and control & 0.58 & 8 & 0.68 & 5 & 0.62 & 2 & 0.63 & 4 \\
\hline
\end{tabular}


Table 2. Cont.

\begin{tabular}{|c|c|c|c|c|c|c|c|c|}
\hline \multirow{3}{*}{ Causes of Changes } & \multicolumn{8}{|c|}{ Organization } \\
\hline & \multicolumn{2}{|c|}{ Owner } & \multicolumn{2}{|c|}{ Consultant } & \multicolumn{2}{|c|}{ Contractor } & \multicolumn{2}{|c|}{ Overall Average } \\
\hline & RII & Rank & RII & Rank & RII & Rank & RII & Rank \\
\hline \multicolumn{3}{|l|}{ Project-related changes } & \multicolumn{6}{|c|}{ RII Average $=0.69$} \\
\hline Project complexity & 0.67 & 4 & 0.72 & 2 & 0.65 & 1 & 0.68 & 3 \\
\hline Inaccurate cost estimating & 0.77 & 1 & 0.77 & 1 & 0.62 & 4 & 0.72 & 1 \\
\hline Short of resources & 0.72 & 3 & 0.71 & 3 & 0.63 & 3 & 0.69 & 2 \\
\hline Change of financial status of any party involved in the project & 0.73 & 2 & 0.66 & 4 & 0.64 & 2 & 0.68 & 3 \\
\hline \multicolumn{3}{|c|}{ Changes related to environment and site conditions } & \multicolumn{6}{|c|}{ RII Average $=0.65$} \\
\hline Difficult site conditions & 0.67 & 2 & 0.67 & 2 & 0.62 & 1 & 0.65 & 2 \\
\hline Unforeseen conditions & 0.67 & 2 & 0.70 & 1 & 0.59 & 2 & 0.65 & 2 \\
\hline Improper site investigation & 0.73 & 1 & 0.67 & 2 & 0.59 & 2 & 0.66 & 1 \\
\hline \multicolumn{3}{|c|}{ Changes related to materials and equipment } & \multicolumn{6}{|c|}{ RII Average $=0.68$} \\
\hline Unavailability of equipment & 0.68 & 2 & 0.75 & 1 & 0.71 & 1 & 0.71 & 1 \\
\hline Specification in materials & 0.68 & 2 & 0.70 & 2 & 0.71 & 1 & 0.70 & 2 \\
\hline Lack of appropriate equipment & 0.78 & 1 & 0.60 & 4 & 0.63 & 2 & 0.67 & 3 \\
\hline Substituting material price & 0.63 & 3 & 0.68 & 3 & 0.62 & 3 & 0.64 & 4 \\
\hline Fluctuation of material prices & 0.73 & 2 & 0.70 & 3 & 0.59 & 2 & 0.67 & 3 \\
\hline \multicolumn{3}{|c|}{ Changes related to economy and governmental regulations } & \multicolumn{6}{|c|}{ RII Average $=0.68$} \\
\hline New government regulations & 0.82 & 1 & 0.73 & 2 & 0.65 & 1 & 0.73 & 1 \\
\hline Changes in government decisions and policies & 0.68 & 3 & 0.65 & 4 & 0.59 & 2 & 0.64 & 3 \\
\hline Changes in the economic conditions of the country & 0.58 & 4 & 0.77 & 1 & 0.65 & 1 & 0.67 & 2 \\
\hline
\end{tabular}




\subsection{Impacts of Changes}

Table 3 presents the field survey showing the results from RII analysis of the effects of changes on the Congolese construction process. This result reveals that changes in management can lead the construction projects into impacts that can affect its performance and success. The RII overall analysis results reveal the organizational and management-related impacts with the higher RII values of 0.69 . Meanwhile, owner and contractor and project, materials, and equipment followed with an equal RII value of 0.67 . The economy and government and design-related changes scored less with the RII values of 0.66 and 0.65 , respectively. These overall impacts of change are presented in Figure 4 . From the above RII results, three main impacts are considered to be the most important which are factors related to organization and management, owner and contractor, and project, materials, and equipment. In the organizational and management-related impacts, disputes between the professionals and inadequate project change management were ranked high with the RII values of 0.76 and 0.70 , respectively. Regular meetings of the main actors involved in the project will reinforce the interpersonal relationships and will decrease any collisions between all stakeholders involved in the project. In addition, a sufficient understanding of the project management objectives will lead the project to meet its objectives (lead the project to successful performance). In the impacts related to the owner and contractor, additional costs for the contractor and disputes between owner and contractor were ranked higher with the RII values of 0.72 and 0.71 , respectively. Changes that could lead to supplementary costs to the contractors should be avoided throughout the project. Finally, in the project related impacts, workers' motivation and productivity loss were ranked first and second with the RII values of 0.73 and 0.71 . It is important for project managers to regularly provide relevant worker incentives and improved management practices in order to contribute to the improvement of the productivity of construction performance [30].

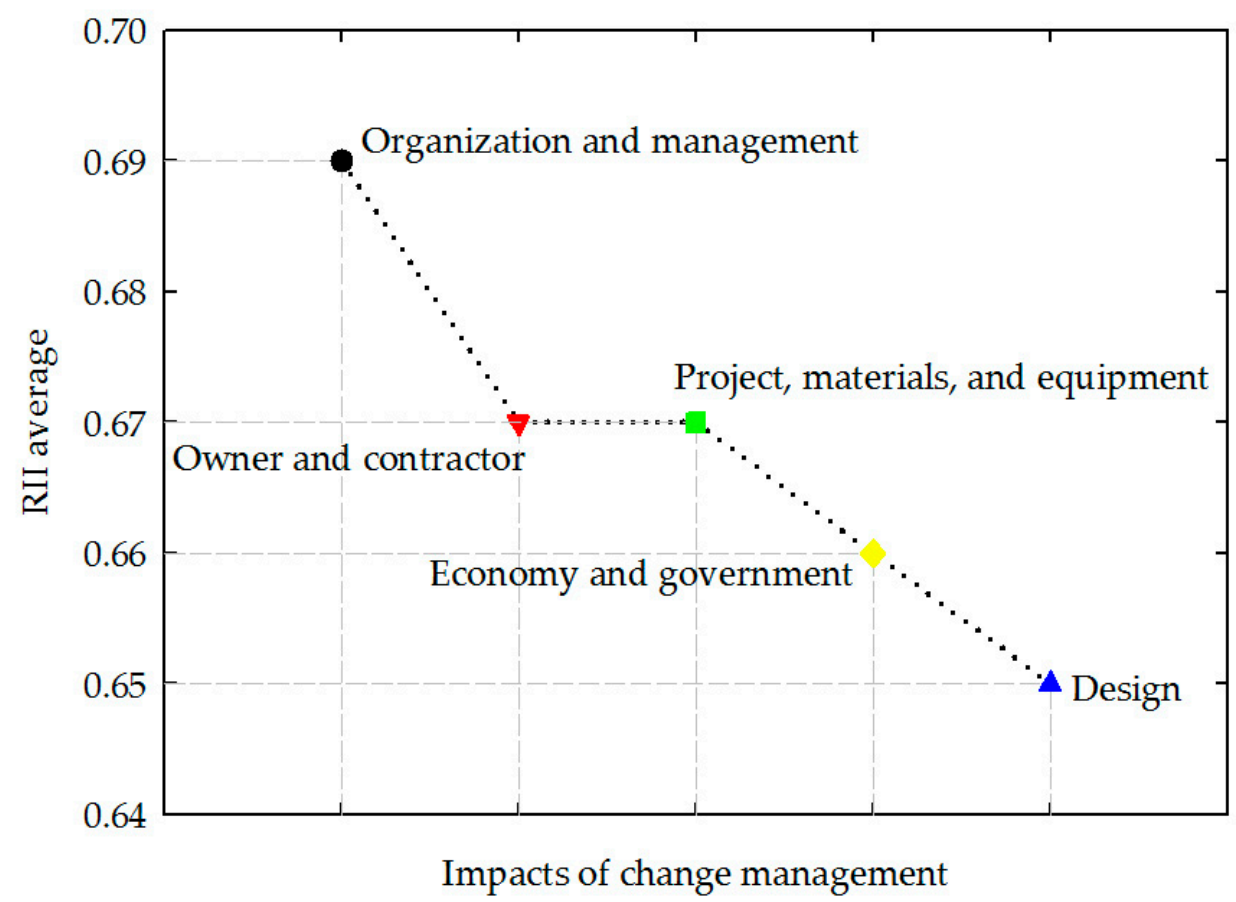

Figure 4. Average for impacts of change management on the project. 
Table 3. Field survey showing the results of the impacts of changes from the RII analysis.

\begin{tabular}{|c|c|c|c|c|c|c|c|c|}
\hline \multirow{3}{*}{ Impacts of Change Management } & \multicolumn{8}{|c|}{ Organization } \\
\hline & \multicolumn{2}{|c|}{ Owner } & \multicolumn{2}{|c|}{ Consultant } & \multicolumn{2}{|c|}{ Contractor } & \multicolumn{2}{|c|}{ OverallAverage } \\
\hline & RII & Rank & RII & Rank & RII & Rank & RII & Rank \\
\hline \multicolumn{3}{|l|}{ Design-related impacts } & \multicolumn{6}{|c|}{ RII Average $=0.65$} \\
\hline Increase design fees & 0.75 & 1 & 0.73 & 1 & 0.69 & 1 & 0.72 & 1 \\
\hline Infective design & 0.73 & 2 & 0.70 & 2 & 0.49 & 4 & 0.64 & 2 \\
\hline Increase chances for design mistakes & 0.57 & 4 & 0.65 & 3 & 0.52 & 3 & 0.58 & 3 \\
\hline Affect project delivery time (completion schedule delay) & 0.67 & 3 & 0.62 & 4 & 0.62 & 2 & 0.64 & 2 \\
\hline \multicolumn{3}{|l|}{ Organizational and management-related impacts } & \multicolumn{6}{|c|}{ RII Average $=0.69$} \\
\hline Affect resource and equipment & 0.73 & 3 & 0.70 & 2 & 0.51 & 4 & 0.65 & 5 \\
\hline Increase supervision fees & 0.67 & 5 & 0.69 & 3 & 0.69 & 2 & 0.68 & 3 \\
\hline Inadequate project change management & 0.72 & 4 & 0.69 & 3 & 0.68 & 3 & 0.70 & 2 \\
\hline Disputes between the professionals & 0.78 & 1 & 0.75 & 1 & 0.74 & 1 & 0.76 & 1 \\
\hline Loss of productivity and efficiency due to interruption and out-of-sequence works & 0.77 & 2 & 0.57 & 4 & 0.68 & 3 & 0.67 & 4 \\
\hline \multicolumn{3}{|l|}{ Impacts related to owner and contractor } & \multicolumn{6}{|c|}{ RII Average $=0.67$} \\
\hline Disputes between owner and contractor & 0.77 & 2 & 0.65 & 5 & 0.72 & 1 & 0.71 & 2 \\
\hline Additional costs for the contractor & 0.73 & 3 & 0.73 & 1 & 0.69 & 2 & 0.72 & 1 \\
\hline Delays in payment to contractor & 0.65 & 5 & 0.70 & 3 & 0.62 & 5 & 0.66 & 4 \\
\hline Increase construction cost & 0.72 & 4 & 0.67 & 4 & 0.66 & 3 & 0.68 & 3 \\
\hline Re-work and demolition & 0.78 & 1 & 0.72 & 2 & 0.54 & 6 & 0.68 & 3 \\
\hline Decrease quality of work & 0.53 & 6 & 0.67 & 4 & 0.65 & 4 & 0.62 & 5 \\
\hline \multicolumn{3}{|l|}{ Impacts related to project, materials, and equipment } & \multicolumn{6}{|c|}{ RII Average $=0.67$} \\
\hline Loss of motivation & 0.83 & 1 & 0.66 & 5 & 0.69 & 2 & 0.73 & 1 \\
\hline Increase chance of frustration and among concerned people & 0.72 & 4 & 0.62 & 6 & 0.71 & 1 & 0.68 & 4 \\
\hline Increase chance for material waste due to re-work operations & 0.77 & 2 & 0.57 & 7 & 0.66 & 4 & 0.67 & 5 \\
\hline Loss of productivity & 0.67 & 5 & 0.74 & 1 & 0.71 & 1 & 0.71 & 2 \\
\hline Poor project management & 0.72 & 4 & 0.71 & 2 & 0.66 & 4 & 0.70 & 3 \\
\hline Decrease in output quality due to the substitution of materials & 0.62 & 4 & 0.67 & 4 & 0.52 & 7 & 0.60 & 8 \\
\hline Revisions to project reports, drawing, and documents & 0.73 & 3 & 0.62 & 6 & 0.57 & 6 & 0.64 & 7 \\
\hline Break of the project due to unavailability of materials & 0.65 & 6 & 0.70 & 3 & 0.63 & 5 & 0.66 & 6 \\
\hline Affect the project delivery time (delay of completion schedule) & 0.63 & 7 & 0.67 & 4 & 0.68 & 3 & 0.66 & 6 \\
\hline \multicolumn{3}{|l|}{ Impacts related to economy and government } & \multicolumn{6}{|c|}{ RII Average $=0.66$} \\
\hline Fluctuation in material price & 0.73 & 1 & 0.56 & 3 & 0.75 & 1 & 0.68 & 1 \\
\hline Increase in tax regulations & 0.68 & 2 & 0.67 & 1 & 0.62 & 3 & 0.66 & 2 \\
\hline Decline in project quality output & 0.60 & 3 & 0.65 & 2 & 0.65 & 2 & 0.63 & 3 \\
\hline \multicolumn{3}{|l|}{ Impacts related to environment and site conditions } & \multicolumn{6}{|c|}{ RII Average $=0.64$} \\
\hline Damage in materials & 0.65 & 3 & 0.67 & 1 & 0.63 & 2 & 0.65 & 1 \\
\hline Delay in the project schedule & 0.75 & 1 & 0.62 & 2 & 0.52 & 3 & 0.63 & 2 \\
\hline Increase in project cost & 0.68 & 2 & 0.53 & 3 & 0.75 & 1 & 0.65 & 1 \\
\hline
\end{tabular}


From the overall results, the peak six single factors that constitute the effects of change management on the project were identified and are presented in Figure 5. The disputes between professionals were ranked first with the RII value of 0.76 . The workers' loss of motivation was ranked second with the RII value of 0.73 . The additional costs for the contractor and the increased design fees were ranked third with the identic RII values of 0.72 . Finally, disputes between the owner and contractor and loss of productivity were ranked fourth with the common RII values of 0.71 .

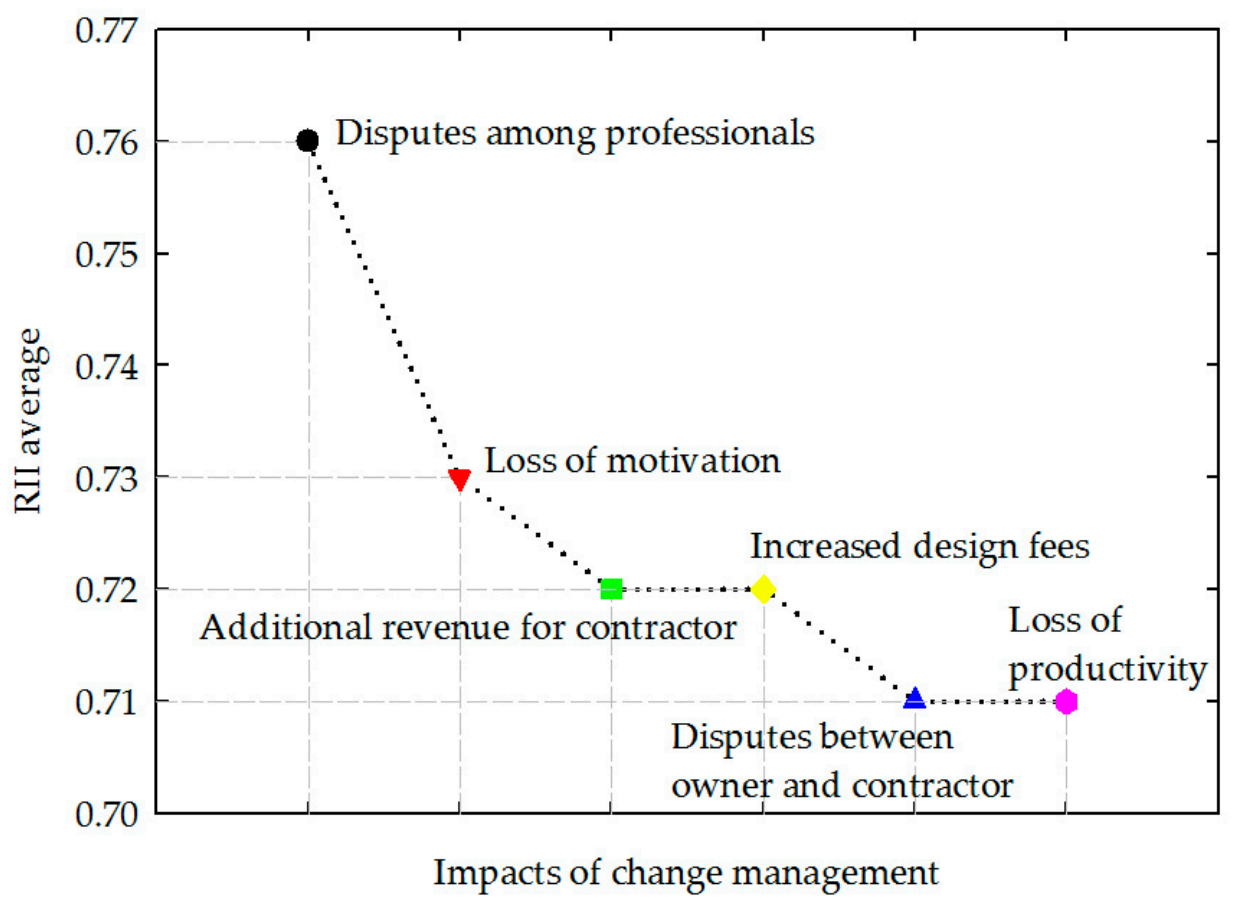

Figure 5. Peak impacts of change management.

\subsection{Correlation Results}

The Spearman's rank correlation was analyzed to define the relationship between two groups of respondents from owners, consultants, and contractors. This correlation coefficient measures the strength and degree of the relationship between respondents. The value of the Spearman (Rho) rank correlation coefficient lies between -1 and +1 which indicates perfect positive correlation $(+1)$, no correlation (0), and perfect negative correlation $(-1)$.

The correlation coefficient of the causes is shown in Table 4. The coefficient between owner and consultant, owner and contractor, and consultant and contractor obtained 0.997, 0.998, and 0.999, respectively. From the respondents, the highest correlation coefficient obtained was between consultant and contractor (strong), but the other two variables (owner vs. consultant and owner vs. contractor) also showed a strong correlation. Table 5 shows the correlation coefficient of the impacts of change management. The correlation coefficient for the impacts of change management indicates a strong $($ Rho $(\rho)=0.999)$ correlation between all the three groups (owner vs. consultant, owner vs. contractor, and consultant vs. contractor) involved in the projects. The results of the above correlation coefficients imply that most of the respondents had almost the same perception about the causes and impacts of change management. 
Table 4. Correlation analysis results of the ranking of the causes of change management.

\begin{tabular}{ccc}
\hline Respondents & Rho $(\rho)=1-\frac{\mathbf{6 \times}\left(\sum \mathrm{di}^{2}\right)}{\mathbf{n} \times\left(\mathbf{n}^{2}-\mathbf{1}\right)}$ & Respondents' Relationship \\
\hline Owner vs. consultant & 0.997 & Strong \\
Owner vs. contractor & 0.998 & Strong \\
Consultant vs. contractor & 0.999 & Strong \\
\hline
\end{tabular}

Table 5. Correlation analysis results of the ranking of the impacts of change management.

\begin{tabular}{ccc}
\hline Respondents & Rho( $\rho)=1-\frac{\mathbf{6 \times}\left(\sum \mathbf{d i}^{2}\right)}{\mathbf{n} \times\left(\mathbf{n}^{2}-1\right)}$ & Respondents' Relationship \\
\hline Owner vs. consultant & 0.999 & Strong \\
Owner vs. contractor & 0.999 & Strong \\
Consultant vs. contractor & 0.999 & Strong \\
\hline
\end{tabular}

\section{Conclusions and Recommendations}

This study investigated the current situation of change management implementation, identified the main causes of change management, and assessed their impacts in the Congolese construction industry. From the results, change management implementation in the Congolese construction industry is significantly higher. Moreover, the factors that have the most influence are the project cost and project type, while the owner's request, project nature, and project size have minimal influence on decision factors to implement the change management.

The causes of change management were identified and concluded with the project-related changes as the top with the RII average of 0.69 . These changes were influenced mostly by inaccurate cost estimating and shortage of resources. Moreover, the contractor-related changes (RII average $=0.68$ ), materials and equipment changes (RII average $=0.68)$, economy and government-related changes (RII average $=0.68)$, design-related changes (RII average $=0.67$ ), organizational and management-related changes (RII average $=0.65)$, environmental conditions (RII average $=0.65)$, and owner-related changes (RII average $=0.64$ ) are the causes of change management in the Congolese construction industry.

From the discussed causes, the impacts of changes on the project completion were studied and are listed below. Organizational and management, owner and contractor, project, materials and equipment, economy and government, and design-related impacts had RII average values of $0.69,0.67,0.67$, 0.66 , and 0.65 , respectively. The disputes between professionals were found to influence the most organizational and management-related impacts with the RII values of 0.76 and 0.70 , respectively, while additional costs for contractor and disputes between owner and contractor were found to be the factors that mostly influence the impacts related to the owner and contractor with the RII values of 0.72 and 0.71 . Furthermore, workers' loss of motivation and loss of productivity in the project affected more the impacts related to project, materials, and equipment with the RII values, respectively, equal to 0.73 and 0.72 .

Knowing the implementation status, causes, and impacts of change management will be a starting point to reduce changes that negatively affect project performance and will allow the Congolese construction industry to boost their opportunities for project success. This study further recommends the improvement of change management. Primarily, construction stakeholders should ensure complete proper estimation of cost considering different factors such as an increase or decrease of tax, material price, and payment. In addition, contractors should minimize the improvement of new work to establish at the site and to ensure the availability of equipment until the completion of the project. Moreover, the design should be finalized before establishing the project to avoid improvements in design while implementing the project, the availability of materials during the project should be ensured, and the environmental conditions of the site investigated thoroughly. The owner should ensure the total finance to complete the project to avoid shortages due to bank loans, bankrupts, and other factors. 
Author Contributions: Conceptualization, S.-H.A. and B.F.B.; methodology, S.-H.A. and B.F.B.; validation, S.-H.A. and B.F.B.; formal analysis, B.F.B.; writing-original draft preparation, B.F.B.; writing-review and editing, B.F.B. and S.-H.A.; supervision, S.-H.A.; funding acquisition, S.-H.A. All authors have read and agreed to the published version of the manuscript.

Funding: This research was supported by the Daegu University Research Grant, 2019.

Acknowledgments: The authors would like to thank Daegu University for its full support and contribution to the realization of this research.

Conflicts of Interest: The authors declare no conflict of interest.

\section{References}

1. Giang, D.T.H.; Sui Pheng, L. Role of construction in economic development: Review of key concepts in the past 40 years. Habitat Int. 2011, 35, 118-125. [CrossRef]

2. Fleming, A.; Senaratne, S.; Sexton, M.; Sun, M.; Aouad, G. Managing project change in construction: The dependency framework. Univ. Salford Res. Inst. Built Hum. Environ. 2004, 65-74. Available online: https://www.irbnet.de/daten/iconda/CIB14553.pdf (accessed on 16 October 2019).

3. Park, M. Dynamic change management for fast-tracking construction projects. In Proceedings of the 19th International Symposium on Automation and Robotics in Construction, Association for Automation and Robotics in Construction: National Institute of Standards and Technology, Gaithersburg, MD, USA, 23-25 September 2002; pp. 81-90.

4. Anees, M.M.; Mohamed, H.E.; Abdel Razek, M.E. Evaluation of change management efficiency of construction contractors. HBRC J. 2013, 9, 77-85. [CrossRef]

5. Mohamad, M.I.; Nekooie, M.A.; Al-Harthy, A.B.S. Design changes in residential reinforced concrete buildings: The causes, sources, impacts and preventive measures. J. Constr. Dev. Ctries. 2012, 17, 23-44.

6. Hwang, B.G.; Low, L.K. Construction project change management in Singapore: Status, importance and impact. Int. J. Proj. Manag. 2012, 30, 817-826. [CrossRef]

7. Bello, A.M.; Saka, A.B. Impact of variation on project delivery in Oyo state. World Sci. News. 2017, 86, 265-282.

8. Moghaddam, A.G. Change management and change process model for the Iranian construction industry. Int. J. Manag. Bus. Res. 2012, 2, 85-94.

9. Endris Yadeta, A. The impact of variation orders on public building projects. Int. J. Constr. Eng. Manag. 2016, 5, 86-91.

10. Lavikka, R.H.; Kyro, R.; Peltokorpi, A.; Sarkilahti, A. Revealing change dynamics in hospital construction projects. Eng. Constr. Archit. Manag. 2019, 26, 1946-1961. [CrossRef]

11. Charles, S.P.R.; Wanigarathna, N.; Sherratt, F. Construction project change: Investigating cost and benefits. In Proceedings of the 31st Annual Association of Researchers in Construction Management Conference, Reading, UK, 7-9 September 2015; Association of Researchers in Construction Management: Reading, UK, 2015; pp. 833-842.

12. Arain, F.M.; Pheng, L.S. Developerse views of potential causes of variation orders for institutional buildings in singapore. Archit. Sci. Rev. 2006, 49, 59-74. [CrossRef]

13. Ndihokubwayo, R.; Haupt, T. Uncovering the origins of variation orders. In Proceedings of the 5th Postgraduate Conference on Construction Industry Development, Bloemfontein, South Africa, 16-18 March 2008; Construction Industry Development Board: Bloemfontein, South Africa, 2008; pp. 88-96.

14. Palaneeswaran, E.; Love, P.E.D.; Kumaraswamy, M.M.; Ng, T.S.T. Mapping rework causes and effects using artificial neural networks. Build. Res. Inf. 2008, 36, 450-465. [CrossRef]

15. Memon, A.H.; Rahman, I.A.; Hasan, M.F.A. Significant causes and effects of variation orders in construction projects. Res. J. Appl. Sci. Eng. Technol. 2014, 7, 4494-4502. [CrossRef]

16. Motawa, I.A.; Anumba, C.J.; Lee, S.; Pena-Mora, F. An integrated system for change management in construction. Autom. Constr. 2007, 16, 368-377. [CrossRef]

17. Dosumu, O.S.; Aigbavboa, C.O. Impact of design errors on variation cost of selected building project in Nigeria. In Proceedings of the Creative Construction Conference, Primosten, Croatia, 19-22 June 2017; Volume 196, pp. 847-856. 
18. Al-Dubaisi, A.H. Change Orders in Construction Projects in Saudi Arabia. Master's Thesis, King Fahd University of Petroleum \& Minerals, Dhahran, Saudi Arabia, 2000.

19. Abdul-rahman, H.; Wang, C. Impacts of design changes on construction project performance. J. Quant. Surv. Constr. Bus. 2017, 7I, 31-54.

20. Desai, J.N.; Pitroda, J. A review on change order and assessing causes affecting change order in construction. J. Int. Acad. Res. Multidiscip. 2015, 2, 12.

21. Peansupap, V.; Cheang, L. Identifying issues of change leading to cost conflicts: Case study in Cambodia. Procedia Eng. 2015, 123, 379-387. [CrossRef]

22. Yadeta, A.E. Recommended strategies to minimize variation orders on public building projects. In Proceedings of the 4th International Conference on the Latest Innovations in Science, Goa, India, 28-30 September 2017; Engineering and Management: Goa, India, 2017; pp. 104-112.

23. Halou, M.I.K.; Samin, R.; Ahmad, M. Impacts of change management on risk and cost management of a construction projects. J. Proj. Manag. 2019, 4, 157-164. [CrossRef]

24. Mbabazi, D.; Warren Kule, J. Effect of change management practices on the performance of road construction projects in Rwanda: A case study of Horizon construction company limited. Int. J. Sci. Res. Publ. 2016, 6, 514.

25. Sun, M.; Fleming, A.; Senaratne, S.; Motawa, I.; Yeoh, M.L. A change management toolkit for construction projects. Archit. Eng. Des. Manag. 2006, 2, 261-271. [CrossRef]

26. Wong, A.K.D.; Wong, F.K.W.; Nadeem, A. Attributes of building information modelling and its development in Hong Kong. HKIE Trans. 2009, 16, 1-8. [CrossRef]

27. Ddes, K.K.; Taiebat, M. BIM experiences and expectations: The constructors' perspective. Int. J. Constr. Educ. Res. 2011, 7, 175-197.

28. Myers, J.L.; Well, A.; Lorch, R.F. Research Design and Statistical Analysis, 2nd ed.; Lawrence Erlbaum Associates Publishers: Mahwah, NJ, USA, 2003; pp. 43-48.

29. Zou, Y.; Lee, S.H. The impacts of change management practices on project change cost performance. Constr. Manag. Econ. 2008, 26, 387-393. [CrossRef]

30. Barg, J.E.; Ruparathna, R.; Mendis, D.; Hewage, K.N. Motivating workers in construction. J. Constr. Eng. 2014, 2014, 1-11. [CrossRef]

Publisher's Note: MDPI stays neutral with regard to jurisdictional claims in published maps and institutional affiliations.

(C) 2020 by the authors. Licensee MDPI, Basel, Switzerland. This article is an open access article distributed under the terms and conditions of the Creative Commons Attribution (CC BY) license (http://creativecommons.org/licenses/by/4.0/). 